\title{
Variation in clinical findings associated with neonatal colibacillosis in lambs before and after treatment
}

\author{
N. Hassan ${ }^{1}$, G. N. Sheikh ${ }^{2}$, S. A. Hussian ${ }^{1}$ and G. Nazir ${ }^{1}$
}

1. Guru Angad Dev Veterinary and Animal Sciences University, Ludhiana, Punjab-141004, India; 2. Department of Veterinary Medicine, Faculty of Veterinary Sciences and Animal Husbandry Sher-e-Kashmir University of Agricultural Sciences \& Technology- Kashmir, Shuhama Campus Srinagar- 190 006, India

Corresponding author: Nuzhat Hassan, email: drnuzhatzargar@gmail.com

Received: 02-02-2014, Revised: 22-03-2014, Accepted: 27-03-2014, Published online: 23-04-2014

doi: $10.14202 /$ vetworld.2014.262-265

How to cite this article: Hassan N, Sheikh GN, Hussian SA and Nazir G (2014) Variation in clinical findings associated with neonatal colibacillosis in lambs before and after treatment, Veterinary World 7(4): 262-265.

\begin{abstract}
Aim: To identify the changes in clinical findings before and after treatment associated with enteric colibacillosis in lambs under different managemental setup.

Materials and Methods: Clinical trial was designed on thirty lambs showing the following signs: scanty fecal volume to profuse watery to whitish diarrhoea, varying degree of dehydration, respiration and heart rate, pale mucous membrane and prolonged capillary refill time.

Results: Clinical signs associated with colibacillosis varied significantly $(\mathrm{P}<0.05)$ before and after treatment. On first day, all the clinical signs were perfectly described and pathogenic Escherichia coli serotypes were isolated from all the affected lambs. Treatment regimen used (antibacterial) in four different groups of clinical cases of colibacillosis indicated gradual improvement and clinical findings started to normalize after the treatment was commenced.
\end{abstract}

Conclusion: The clinical severity may vary according to the number of organisms and the physiological condition of the affected animals. Skin fold test was a more significant indicator of dehydration and fluid loss in diarrheic lambs than eyeball recession. Capillary refill time was a reliable and a significant indicator of peripheral perfusion among diarrheic lambs.

Keywords: clinical signs, colibacillosis, dehydration, lambs.

\section{I ntroduction}

New born farm animals are highly vulnerable to infections and diseases as they possess negligible concentrations of circulating immunoglobulins. Colibacillosis is one of the important neonatal diseases, most common in lambs occurring during first few days to few weeks of life [1]. The disease is caused by pathogenic serotypes of Escherichia coli [2,3]. E. coli has been associated with two forms of enteric and septicemic infections with the enteric form being more commonly observed in 2 to 8 day old lambs, characterized by varying degree of diarrhea, dehydration, acidosis and death in few days if untreated $[4,5]$. The septicemic form in lambs at 2 to 6 weeks of age is characterized by severe illness and rapid death [6]. Generally, affected animals are depressed and weak, commonly recumbent, and dehydrated; tachycardia is present and the body temperature may be variable. The suckle reflex is either weak or absent, the oral mucous membranes are dry and cool, and capillary refill time may be prolonged. However, there are no diagnostic clinical signs that can differentiate the disease but clinical findings at first pave a way to start an effective diagnostic and therapeutic strategy [7]. Although sheep husbandry is an important component of livestock sector of $\mathrm{J} \& \mathrm{~K}$ state, early

Copyright: The authors. This article is an open access article licensed under the terms of the Creative Commons Attribution License (http://creativecommons.org/licenses/by/2.0) which permits unrestricted use, distribution and reproduction in any medium, provided the work is properly cited. lamb mortality due to neonatal Colibacillosis is one of the stumbling blocks for its expansion and to reap economic benefits.

An understanding of the clinical signs associated with this infection is therefore, important for the development of effective intervention strategies to control this disease $[8,9]$.

\section{Materials and Methods}

Ethical approval: Study was performed after the permission of the Institutional Animal Care.

Experimental design: Studies on the variations in clinical findings associated with colibacillosis in lambs were conducted during different seasons (winter, spring, summer and autumn) at different geographical areas that included both organized and unorganized farms. The clinical trials were designed on thirty lambs exhibiting the symptoms of diarrhea and dehydration and were divided into five groups (six animals each). Four drug regimens were used in four groups which included different antibacterials viz; (Group-I: Ciprofloxacin-4mg/kg body weight, Group-II: Co-trimoxazole$15 \mathrm{mg} / \mathrm{kg}$ body weight, Group-III: Neomycin- $10 \mathrm{mg} /$ $\mathrm{kg}$ body weight Group-IV: Gentamicin - 4mg/kg body weight respectively twice daily for four days). Whereas, one of the groups acted as infected untreated control and other group of six healthy lambs was kept as healthy control group. For conducting studies on the variation in clinical findings associated with colibaci- 
Table-1: Difference in Clinical signs before and after treatment.

\begin{tabular}{|c|c|c|c|c|c|c|c|c|c|c|c|c|}
\hline \multirow[t]{2}{*}{ Tests } & \multicolumn{2}{|c|}{ Healthy } & \multicolumn{2}{|c|}{$\begin{array}{l}\text { Infected and } \\
\text { untreated group }\end{array}$} & \multicolumn{2}{|c|}{ Group-I } & \multicolumn{2}{|c|}{ Group-II } & \multicolumn{2}{|c|}{ Group-III } & \multicolumn{2}{|c|}{ Group-IV } \\
\hline & $\begin{array}{l}0 \text { day } \\
\text { Sec(\%) }\end{array}$ & $\begin{array}{l}6^{\text {th }} \text { day } \\
\text { Sec }(\%)\end{array}$ & $\begin{array}{l}0 \text { day } \\
\text { Sec }(\%)\end{array}$ & $\begin{array}{l}6^{\text {th }} \text { day } \\
\operatorname{Sec}(\%)\end{array}$ & $\begin{array}{l}\mathbf{0} \text { day } \\
\text { Sec }(\%)\end{array}$ & $\begin{array}{l}6^{\text {th }} \text { day } \\
\operatorname{Sec}(\%)\end{array}$ & $\begin{array}{l}0 \text { day } \\
\text { Sec }(\%)\end{array}$ & $\begin{array}{l}6^{\text {th }} \text { day } \\
\operatorname{Sec}(\%)\end{array}$ & $\begin{array}{l}0 \text { day } \\
\text { Sec }(\%)\end{array}$ & $\begin{array}{l}6^{\text {th }} \text { day } \\
\text { Sec }(\%)\end{array}$ & $\begin{array}{l}\text { O day } \\
\text { Sec }(\%)\end{array}$ & $\begin{array}{l}6^{\text {th }} \text { day } \\
\text { Sec }(\%)\end{array}$ \\
\hline $\begin{array}{l}\text { Skin Fold Test } \\
\text { Depth of } \\
\text { Enophthalmos }(\mathrm{mm})\end{array}$ & $\begin{array}{l}2(0) \\
\mathrm{Nil}\end{array}$ & $\begin{array}{l}1.6(0) \\
\text { Nil }\end{array}$ & $\begin{array}{l}5.1(6-8) \\
<3(<6)\end{array}$ & $\begin{array}{l}3(2) \\
1(2)\end{array}$ & $\begin{array}{l}4(4) \\
2(4)\end{array}$ & $\begin{array}{l}1.8(0) \\
\text { Nil }\end{array}$ & $\begin{array}{l}4.3(4-6) \\
2(4)\end{array}$ & $\begin{array}{l}1.5(0) \\
\mathrm{Nil}\end{array}$ & $\begin{array}{l}3.5(2-4) \\
1(2)\end{array}$ & $\begin{array}{l}1.3(0) \\
\mathrm{Nil}\end{array}$ & $\begin{array}{l}3.8(2-4) \\
2(4)\end{array}$ & $\begin{array}{l}1.3(0) \\
\text { Nil }\end{array}$ \\
\hline Capillary refill time & $2(1.67)$ & $2(1.33)$ & $2(3.67)$ & $2(2.67)$ & $2(3.33)$ & $2(1.67)$ & $2(3.17)$ & $2(1.33)$ & $2(3.33)$ & $2(1.50)$ & $2(3.50$ & $2(1.50)$ \\
\hline
\end{tabular}

llosis, rectal swabs were collected from diarrheic lambs below the age group of 8 -weeks irrespective of their sex and breed for the isolation of $E$. coli. These lambs were reared under different managemental conditions. Rectal swabs were collected aseptically and processed within 2 to 4 hours for the isolation and identification of $E$. coli using standard cultural, microbiological and biochemical tests [10]. Detailed symptoms and clinical observations were recorded in all the animals of different groups. Systematic clinical examination was done, starting from the 0 day before treatment and up to sixth day of post treatment. The variations in clinical signs were regularly monitored till the animals showed clear signs of recovery. The clinical symptoms recorded were:

A) Vital parameters

Temperature $\left({ }^{0} \mathrm{~F}\right)$

Respiration Rate (breaths/min)

Pulse Rate (pulsation/min)

Heart Rate (beats/min)

The hydration status of the animal was determined on the basis of:

i) Cervical Skin fold test (sec): The skin fold test was performed by tenting the skin of the lateral portion of the cervical region of neck and measuring the time (seconds) required for the skin fold to return to normal.

ii) Visible mucous membranes and extremities: Oral mucosa was examined for the presence of visible color. iii) Capillary refill time (C.R.T.) (sec): It was evaluated for peripheral perfusion. The C.R.T. was checked by pressing the gums with a finger or thumb firmly to blanch the area then measuring the time it takes to return to normal color.

iv) Depth of enophthalmos (mm): Recession of eyeball was determined by visual evaluation of the gap formed between the eyeball and the orbit when the medial canthus of the eye was manually opened.

Statistical analysis: The results were subjected to two way ANOVA statistical analysis [11].

\section{Results and Discussion}

In order to confirm the presence of pathogenic $E$. coli, the cultural examination of faecal samples collected from diarrheic lambs, was done. All the $E$. coli isolates were sent to National Salmonella and Escherichia Centre Kasouli (Himachal Pradesh) for Serotyping. The cases in which pathogenic $E$.coli isolates were obtained from the faecal samples were taken for further study. The lambs suffering from colibacillosis presented variable clinical symptoms of disease like scant fecal volume to profuse waterywhitish diarrhea, soiling of perineum and tail, mild dehydration, rough body coat, dry mouth/muzzle, tachycardia, pale mucous membrane, prolonged capillary refill time, profound weakness, slight increase in rectal temperature and increased respiration rate. Weight loss and decrease in appetite (poor suckling effect) was also recorded [12, 13]. Diarrhea or scouring occurs when the capability of the intestine to absorb fluid is impaired. Interference with this absorptive function of the intestine occurs due to damage to the cells lining the intestine, may result from cell destruction by infectious agents $(E$. coli $)$, resulting in loss of the digestive and absorptive capability of the intestine as well as inflammation $[14,15]$.

Clinical evaluation of dehydration: The hydration status of the diarrheic lambs as revealed by skin fold test is represented in Table-1. In infected groups, the degree of dehydration varied from moderate (6-8\%) on day 0 to up to barely detectable (2-4\% of body weight) on day $4^{\text {th }}$ and $6^{\text {th }}$ post treatment in different groups. The hydration status of the diarrheic lambs as revealed by recession of eyeball indicated that the overall recession of eyeball recorded in different infected groups on day 0 varied between $2-1 \mathrm{~mm}$ indicating $2-4 \%$ dehydration as compared to healthy control group. The hydration status of the diarrhoeic lambs as revealed by capillary refill time suggested that in infected untreated groups, on day 0 capillary refill time was significantly high as compared to healthy control, whereas there was a progressive decrease from 48 hours post treatment groups and by $6^{\text {th }}$ day ( $144 \mathrm{hrs}$ ) capillary refill time in different treatment groups was almost comparable to healthy control group. There was a definite increase in the skin fold time in the diarrheic lambs which was indicative of decreased skin elasticity due to extracellular fluid loss in these animals. An average skin fold time of 4.3 seconds, which was recorded in the present study, corresponded approximately to the dehydration of 4-6\% [16]. There was no significant change in eyeball recession in the diarrheic lambs from the present study. Skin fold test was thus a more significant indicator of dehydration and fluid loss in diarrheic lambs. Eyeball recession as indicator of dehydration has also been reported [17]. There was also increase in capillary refill time with an average of 3.33 seconds in the diarrhoeic lambs as compared to healthy lambs which was indicative of compromised circulating volume and a reduced peripheral perfusion 
Table-2: Difference in clinical signs before and after treatment

\begin{tabular}{|c|c|c|c|c|c|c|}
\hline Clinical signs & Healthy & $\begin{array}{l}\text { Infected and } \\
\text { untreated group }\end{array}$ & Group-I & Group-II & Group-III & Group-IV \\
\hline \multicolumn{7}{|c|}{ Respiration rate (breaths/min) } \\
\hline 0 day & $36.51 \pm 1.58^{\mathrm{aA}}$ & $45.83 \pm 2.75^{\mathrm{aB}}$ & $39.50 \pm 0.76^{\mathrm{aB}}$ & $39.51 \pm 0.77^{\mathrm{aB}}$ & $44.17 \pm 2.41^{\mathrm{aB}}$ & $43.83 \pm 2.36^{\mathrm{aB}}$ \\
\hline \multicolumn{7}{|c|}{ Rectal Temperature ( $\left.{ }^{\circ} \mathrm{F}\right)$} \\
\hline 0 day & $102.65 \pm 0.08^{\mathrm{aA}}$ & $102.35 \pm 0.34^{\mathrm{aA}}$ & $103.76 \pm 0.84^{\mathrm{aA}}$ & $103.21 \pm 0.52^{\mathrm{aA}}$ & $103.80 \pm 0.47^{\mathrm{aAB}}$ & $103.80 \pm 0.47^{\mathrm{aAB}}$ \\
\hline \multicolumn{7}{|c|}{ Pulse rate (pulsation/min) } \\
\hline 0 day & $72.66 \pm 1.72^{\mathrm{aA}}$ & $74.33 \pm 2.09^{\mathrm{aA}}$ & $81.00 \pm 2.36^{\mathrm{aC}}$ & $77.84 \pm 4.04^{\mathrm{aB}}$ & $82.50 \pm 1.61^{\mathrm{aC}}$ & $74.83 \pm 2.06^{\mathrm{bA}}$ \\
\hline \multicolumn{7}{|c|}{ Heart Rate (beats / $\mathrm{min}$ ) } \\
\hline 0 day & $74.00 \pm 1.93^{\mathrm{aA}}$ & $74.50 \pm 1.56^{\mathrm{aA}}$ & $82.34 \pm 1.29^{\mathrm{aC}}$ & $78.83 \pm 2.62^{\mathrm{aB}}$ & $81.33 \pm 1.45^{\mathrm{aC}}$ & $74.83 \pm 1.56^{\mathrm{bA}}$ \\
\hline 6th day & $88.33 \pm 2.11^{\mathrm{ac}}$ & $72.67 \pm 0.71^{\mathrm{cA}}$ & $82.67 \pm 1.67^{\mathrm{aC}}$ & $72.33 \pm 2.03^{\mathrm{bA}}$ & $87.33 \pm 1.63^{\mathrm{aC}}$ & $74.17 \pm 1.40^{\mathrm{cA}}$ \\
\hline
\end{tabular}

Values with similar superscript (Capital letters-between groups and small letters -Within groups) do not differ significantly ( $P>0.05$ )

in these animals. Similar findings have been reported previously [18].

Respiration rate (breaths/ min): The respiration rates recorded in different infected groups were significantly $(\mathrm{P}<0.05)$ higher as compared to healthy control but lower to infected untreated control on day '0' (Table-2). Progressive decrease in respiration rate was observed on successive days of post treatment and at 144 hours, significantly lower respiration rate values were recorded in all treatment groups as compared to infected untreated control but values were comparable to healthy control [22].

Rectal Temperature $\left({ }^{\circ} \mathbf{F}\right)$ : The recorded rectal temperature in infected groups on day 0 was significantly higher as compared to healthy control. In first two treatment groups there was a progressive decrease in the rectal temperature by $4^{\text {th }}$ day post treatment but was nonsignificant, whereas, in other two treatment groups, there was a significant decrease in the rectal temperature by four days post treatment (Table-2). By day six post treatment, the rectal temperature in all treatment groups was comparable to healthy control group. All the lambs naturally infected with $E$. coli showed signs of higher rectal temperature varying from 103.5 to $104^{\circ}$ $F$ with a mean of $104.20 \pm 0.14^{\circ} \mathrm{F}$ indicative of bacterial infection and/or septicemia responsible for higher body temperature. These observations support the earlier reports in neonatal septicemic calves [19-21].

Pulse rate (pulsation/ $\mathbf{m i n}$ ): The mean pulse rate in all infected groups was significantly higher as compared to healthy control at ' 0 ' day pre-treatment (Table-2). In three treatment groups significant decrease in pulse rate was observed by $4^{\text {th }}$ day post treatment, whereas, in forth treated group significant decrease was recorded at 144 hours post treatment as compared to their respective values on day 0 . By $6^{\text {th }}$ day the mean pulse rate recorded in all treatment groups the pulsation/min respectively was significantly lower as compared to infected untreated control but comparable to healthy control.

Heart Rate (beats / min): The mean heart rate in all infected was significantly higher as compared to healthy control at ' 0 ' day pre-treatment. In three treatment groups, there was significant decrease in heart rate, evident at 96 hours post treatment, whereas, in fourth treated group significant decrease was observed at 144 hours post treatment when compared to respective values on day 0 . By day 6 (144 hours) the mean heart rate in all treated groups was significantly lower as compared to infected untreated control but comparable to healthy control. A marked increase in respiration rate was recorded in E. coli infected lambs as compared to healthy lambs. The variation in the depth and rate of respiration may be because of dehydration which leads to hyperpnoea and polypnea. The variation in heart rate and pulse rate may be probably because of metabolic upsets as reported previously [23-25].

\section{Conclusion}

On perusal of the results obtained in the present study, we conclude that the clinical signs associated with colibacillosis varied significantly before and after treatment. On first day, all the clinical signs were perfectly described and pathogenic E. coli serotypes were isolated from all the affected lambs; however by day six there was a gradual improvement in the signs and symptoms after the treatment. The clinical findings varied according to the severity of the disease and the immediate treatment regimen that was started from day confirmed a great response in the treated animals. After the diarrhea is evident, the outstanding clinical signs associated with colibacillosis are a varying degree of dehydration, variations in respiration and heart rate. The prognosis of the disease is good if the treatment regimen is started immediately after onset of clinical signs.

\section{Authors' contributions}

NH and GNS: designed and planned the study. The experiment and case study was done by NH and GNS. Results were interpreted and formulated by GNS, NH, GN and SAH. All authors participated in draft and revision of the manuscript. All authors read and approved the final manuscript. 


\section{Acknowledgments}

The authors would like to thank the Division of Veterinary Medicine and PG studies of SKUAST-K for providing full assistance and funding throughout the research studies.

\section{Competing interests}

The authors declare that they have no competing interests.

\section{References}

1. Panda, S.N., Acharya, S.N. and Mishra, B.C. (1965) Colibacillosis in goats, a study of serotype involved. Indian Vet J., 42 : 553- 558 .

2. Gyles, C.L. (1994) E. coli in domestic animals and Humans. Wallingford, UK: CAD. p171-191.

3. Hemashenpagam, N., Kiruthiga, B., Selvaraj, T. and Panneerselvam, A. (2009) Isolation, Identification and Characterization of Bacterial pathogens causing Calf Diarrhea with special reference to Escherichia coli. The Int J Microbiol., 7(2).

4. Kaske, M. (1994) Patho-physiological aspects of neonatal diarrhoea. Tierarz. Umchan., 49:336-348.

5. Osman, K.M., Mustafa, A.M., Elhariri, E. and AbdElhamed, G.S. (2013) The Distribution of Escherichia coli Serovars, Virulence Genes, Gene Association and Combinations and Virulence Genes Encoding Serotypes in Pathogenic E. coli Recovered from Diarrhoeic Calves, Sheep and Goat. Transbound Emerg Dis., 60. 69-78.

6. Sojka, W.J. (1971) Enteric diseases in newborn piglets, calves and lambs due to Escherichia coli infection. Vet. Bulletin (London)., $41: 509-522$.

7. Mahmoud, A.H., Abdellrazeq, G.S., Akeila, M.A. and Khadr, A.M. (2013) Association of antimicrobial resistance with plasmid and protein profiles in Enterohemorrhagic Escherichia coli isolated from calves, lambs and fish. Alexandria J. Vet. Sci., 38: 137-145.

8. Ahmed, A. (2009) Epidemiological studies on some causes of lamb mortality in Sokoto state. PhD. Thesis. Usmanu Danfodiyo University, Sokoto, p198.

9. Pourtaghi, H., Dahpahlavan, V. and Hassan, M. 2013. Virulence genes in Escherichia coliisolated from calves with diarrhoea in Iran. Comp Clin Pathol., 22 (3): 13-51.

10. Sharma, M.M., Mathur, P.B., Kumar, P.N. and Uppal, P.K. (1981) Causes of mortality in lambs under semi-arid climate conditions of Rajasthan. Indian Vet J., 58(11) : 859-864.

11. Barrow, G. I. and Felham, R.K.A. (1992) Cowan and steel's Manual for the identification of Medical Bacteria. II Edn.
University Press, Cambridge. p77-82.

12. Snedecor, C.S. and Cochran, W.G. (1994) Statistical methods, $8^{\text {th }} \mathrm{Ed}$. The Iowa State University Press, Ames, Iowa, USA. p439.

13. Nguyen, T. D.,Vo, T.T. and Vu-Khac, H. (2011) Virulence factors in Escherichia coli isolated from calves with diarrhea in Vietnam. J Vet Sci., 12: 159-164.

14. Chaarani, B., Robinson, R.A. and Johnson, D.W. (1991) Lamb mortality in Mekness province (Morocco). Prev Vet Med., 10(4) : 283-298.

15. Radostits, O. M., Blood, D. C., Gay, C. G. and Hinchcliff, K.W. (2000). Veterinary Medicine. IX Edn. W.B. Saunders, p1494.

16. Schoenian S. (2006). Diarrhoea (scours) in small ruminants. In: Small Ruminant Fact Sheet Series. University of Maryland Cooperative Extension. p1-4.

17. Radostits, O. M., Blood, D. C., Gay, C. G. and Hinchcliff, K.W. (2003) Veterinary Medicine. IX Edn. W.B. Saunders, p1499.

18. Constable, P.D., Walker, P.G. and Morin, D.E. (1998). Clinical and laboratory assessment of hydration status of neonatal calves with diarrhoea. $J$ Vet Med Assoc., 212 : 991996.

19. Radostits, O. M., Blood, D. C. and Gay, C. G. (1994). Veterinary Medicine. VIII Edn. Bailliere Tindal, London, p473-486.

20. Gomez, L., Andres, S., Sanchez, J., Alonso, J. M., Rey, J., Lopez, F. and Jimenez, A., (2008) Relationship between the treatment and the evolution of the clinical course in scouring Merino lamb from "La Serena" (Southwest Spain). Small Ruminant Res., 76:223-227.

21. Samad, M.A., Islam, M.A., Hossain, K.A., Islam, M.T. and Saha, S. (2003) Haemato-biochemical changes and antibiotic sensitivity of $E$. coli associated with concurrent enteric and septicemic infection in calves. Bangladesh JVet Med., 1 (1):39-43.

22. Aldridge, B.M., Garry, F.B. and Adams, R. (1993) Neonatal septicemia in calves. JAm Vet Assoc., 203: 1324-1329.

23. Ershaduzzaman, M., Taimur, M.J.F.A., Tanuza Das, Mamunul M. H, and Mahmudur M.R. (2013) Epidemiological Studies on Kid Diseases Associated with Morbidity and Mortality in Intensive and Semi-Intensive Systems in Bangladesh," Int. J. Innovation Appl. Stud., 3 (2): 456-462.

24. Kumar, R., Mandial, R.K. and Gupta, N. (2002) Clinicobiochemical and therapeutic studies on clinical colibacillosis in cross bred calves. Indian J Vet Med., 22(1): $1-3$.

25. Uetake, K. (2013) Newborn calf welfare: A review focusing on mortality rates. Animal Sci J., 84: 101-105. 